\title{
Importance of folate in human nutrition
}

\author{
Kamala Krishnaswamy* and K. Madhavan Nair \\ National Institute of Nutrition, Jamai-Osmania, Hyderabad-500007, India
}

\begin{abstract}
From a public health perspective, some of the new insights into folic acid nutrition are of significance. Folate intake recommendations vary under different conditions. Intake of $350 \mu \mathrm{g}$ is required to maintain plasma homocysteine levels, $650 \mu \mathrm{g}$ for those with elevated plasma homocysteine, about $400 \mu \mathrm{g}$ for women planning to become pregnant and $4000 \mu \mathrm{g}$ for those with history of neural tube defect affected pregnancy. This raises the question whether the folate intake is adequate for the general population, particularly in the vulnerable groups or whether there is a need for scientists to take a fresh view of the requirements, recommended dietary intakes, and consider intervention measures which will have impact on the folate nutritional status. The recommendations should provide a margin of safety to allow for decreased intake, increased requirements, individual variability and bioavailability of natural food folates. The folate intake and nutriture in relation to India and other developing countries needs careful consideration to reduce anemia, neural tube defects and possibly impact on the high incidence of cardiovascular diseases.
\end{abstract}

Folate: Homocysteine: Health and disease: RDA: India

Folate is the generic term for compounds that have vitamin activity similar to that of pteroylglutamic acid and is an anti-anemic and growth factor. Folate acts as a co-enzyme in several single carbon transfers leading to the biosynthesis of purine nucleotides and deoxythymidylic acid essential for DNA and RNA synthesis. In general, rapidly growing and multiplying cells require an adequate supply of folate. As it participates in several biochemical functions, it is important to consider conditions that increase the risk of folate deficiency and its consequences.

\section{Food folate - digestion, absorption and availability}

Folate exists in many chemical forms (Wagner, 1996). Mammals are unable to synthesize a pteridine ring, one of the three groups of tetrahydrofolate; the other two groups are p-aminobenzoate and glutamate. They obtain tetrahydrofolate from their diets or from microorganisms in their intestinal tract. Naturally occurring folates, called food folate (polyglutamyl chain) are present both in animal and plant foods. Organ meats such as liver and egg yolk are fairly good sources of folate and in the Indian context the major sources are legumes and green leafy vegetables. The intake of folate based on the NNMB (1999) suggested that as per the existing recommendations more than $60 \%$ of folate nutrition is met from cereals and pulses (Fig. 1).
The intestinal absorption of folate occurs at the monoglutamyl level. Therefore dietary folates, most of which are polyglutamyl derivatives, undergo hydrolysis in the gut to monoglutamates before absorption, across the intestinal mucosa (Butterworth et al. 1969). In the absence of protecting agents such as ascorbic acid and reduced thiols, many labile folates may be lost during residence in the acid peptic milieu of the stomach. Other food constituents affect action of the intestinal hydrolases. Absorption of monoglutamate predominantly occurs in the duodenum and jejunum by an active transport in a saturable $\mathrm{pH}$ dependent process. By far the majority of intracellular folates are polyglutamates. In contrast, extracellular folates are monoglutamates (Cossins, 1984). For folate absorption, luminal digestion to the monoglutamyl form by an intestinal enzyme known as folate conjugase found in the brush border is the rate limiting step. This enzyme is an exopeptidase and is activated by zinc (Chandler et al. 1986). A second enzyme, intracellular hydrolase, is found in the lysosomes of intestinal cells, has a $\mathrm{pH}$ optimum of 4.5 and is an endopeptidase (Wang et al. 1986). The function of the former is believed to be primarily in the digestion of dietary folates and that of the latter is still unknown. Monoglutamates are present in portal circulation, which is taken by the liver and converted to polyglutamate derivatives and stored or released into the

Abbreviations: DNA, dioxyribonucleic acid; RNA, ribonucleic acid; AUC, area-under-the-plasma-response-curve; RBC, red blood cells; NTD, neural tube defects; CAD, coronary artery disease; Hcy, homocysteine; HDL, high density lipoprotein; MTHFR, methylenetetrahydrofolate reductase; FDA, Food and Drug Administration, United States of America; EAR, estimated average requirement; DRI, dietary reference intakes; RDA, recommended daily allowances; DFE, dietary folate equivalents; RDI, recommended dietary intake.

* Corresponding author: Dr Kamala Krishnaswamy, fax +9140 7019074, email icmrnin@ren.nic.in, nin@ap.ap.nic.in 


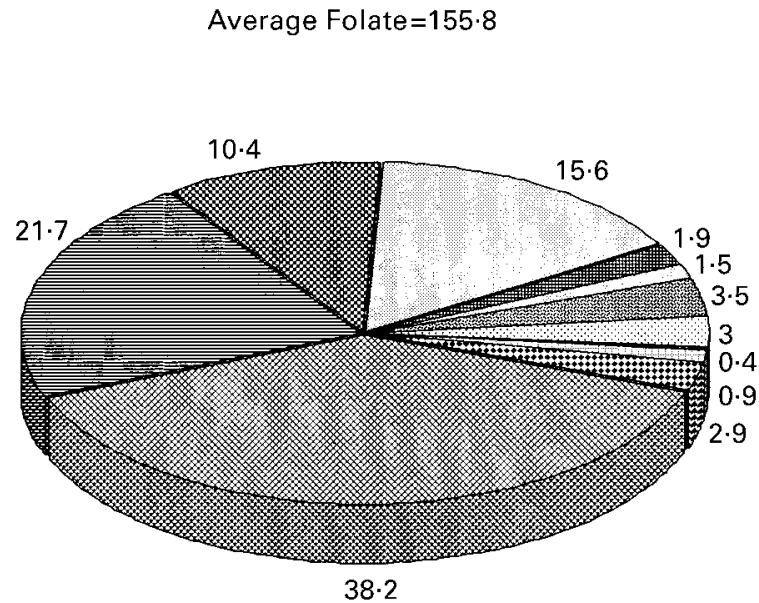

$38 \cdot 2$

Cereals
旾 Pulses
GLV
$\square$ Other Veg
Roots \& Tubers
$\square$ Nuts \& Oil seeds
疄 Condiments
$\square$ Fruits
$\square$ Fish
$\square$ Other Flesh Foods
Milk \& Milk Prod.

Source: NNMB Repeat Survey 1996-97

Fig. 1. Folic acid distribution from different foods ( $\mu \mathrm{g} / \mathrm{CU})$.

blood. In plasma, folate is bound primarily to albumin. Cellular transport of folate is mediated through a number of different folate transport systems.

Information on the availability of food folate is fragmentary. The paucity of information stems primarily from the complexity of dietary folates, their low levels, presence of dietary inhibitors and the limited ability to distinguish between newly absorbed folate and endogenous folate. Seyoum \& Selhub (1998) developed an in vitro method based on the stability and susceptibility to intestinal pteroylpolyglutamate hydrolase action. Folate availability generally varies widely among foods. The maximum availability is found in egg yolk $(72.2 \%)$ followed by cow's liver $(55.7 \%)$; there is a low availability from vegetables $(3-6 \%)$. The absorption of folate from foods varies from $25 \%$ to $70 \%$ with a mean close to about $50 \%$ (Tamura \& Stokstad, 1973; Babu \& Srikantia, 1976).

Synthetic folic acid (a stable oxidized form of pteroylmonoglutamate, often used to correct folate deficiency) is considered to be more bioavailable than natural folate. The bioavailability of supplements of folic acid under fasting conditions are close to $100 \%$ (Gregory, 1997). Folic acid absorption in both pregnant and non-pregnant Indian women was studied by Iyengar \& Babu (1975) using ${ }^{3} \mathrm{H}$ folic acid and $2 \mathrm{mg}$ of cold folic acid. The absorption of folic acid varied from $72 \%$ to $94 \%(n=9)$ with a mean absorption of $82 \%$ which was similar to that obtained in non-pregnant women $(n=6)$. On the other hand, food folate is less bioavailable than the synthetic form (Sauberlich et al. 1987; Cuskelly et al. 1996). It has been recently demonstrated based on plasma folate that the bioavailability of folate from spinach can be improved by disruption of the vegetable matrix (vanhet Hof et al. 1999).

Currently, there are many accurate methods of estimating the food folate level and their bioavailabilities. The procedures for the various methods of food folate determination have been reviewed by Tamura (1998). It is now well established that the 'trienzyme method' namely alpha-amylase and protease for the extraction of folate trapped in or bound to protein and carbohydrate matrices and the enzyme folate conjugase for the hydrolysis of polyglutamyl folate, be used to obtain the actual maximum content of folate in each food item. According to PrinzLangenohl (1999) the AUC method with multiple blood sampling is useful for assessing the availability of food folate in humans. Using this method a significantly greater absorption of $400 \mu \mathrm{g}$ of folic acid than with the same amount of food folate was reported in normal pregnant women (Neuhouser et al. 1998). The use of a single dose, dual-label, stable-isotope method was employed by Pfeiffer et al. (1997) to assess the absorption of folic acid from fortified cereal grain products. Isotope excretion ratios of urinary folates that were used as criteria of availability, indicated that the folic acid in these foods was highly bioavailable. Thus it is evident that there is a need to augment research in this area in India not only to generate reliable food folate tables but also its availability to Indians using these techniques.

\section{Losses of food folate}

Most natural folates are unstable and destroyed during various cooking procedures and also by oxidation and ultraviolet light (O'Broin et al. 1975; Dawson \& Waters, 1994). Food processing can cause considerable losses of folate for example in canning, in prolonged heating, when cooking water is discarded and from reheating. Reducing agents in food such as ascorbic acid provide greater stability to the vitamin. Indian cooking practices such as heating for prolonged periods in open vessels probably destroy and reduce food folates considerably. Germination, however, increases food folate availability (Babu, 1976a).

\section{Folate status}

Biochemical assessment of folate nutritional status is most commonly done by measuring serum and $\mathrm{RBC}$ folate levels. Serum folate essentially reflects recent intake and 
Table 1. Folate nutriture of Indians $†$

\begin{tabular}{lcccc}
\hline & No. & RBC folate nmol/L & Cutoff level nmol/L & Per cent deficient \\
\hline $\begin{array}{l}\text { Men }(25-50 \text { y) } \\
\text { Women }\end{array}$ & 45 & $323 \pm 97$ & 180 & 8 \\
$(25-50$ y) & 25 & $371 \pm 169$ & - & - \\
Pregnant women & 43 & $309 \pm 81$ & - & - \\
$<16$ wk & 60 & $310 \pm 153$ & 284 & $53 \cdot 3$ \\
$17-20$ wk & 77 & $337 \pm 26$ & 284 & $40 \cdot 5$ \\
$21-24$ wk & 84 & $348 \pm 175$ & 284 & $50 \cdot 0$ \\
$25-28$ wk & 30 & $347 \pm 185$ & 284 & 25 \\
Pregnant women & 115 & $287 \pm 117$ & 284 & 20 \\
$(1 \& 2$ Trimesters) & & & 180 & \\
Children (1-5 y) & 246 & $267 \pm 90$ & & \\
(Boys \& girls) & & & & \\
\hline
\end{tabular}

Values are means $\pm \mathrm{SD}$.

† Ahmed et al. 1975; Babu, 1976b; Neela \& Raman, 1997; Raman et al. 1989.

red cell levels represent long term tissue stores. It is generally accepted that serum folate values above $14 \mathrm{nmol} /$ $\mathrm{L}$ or $\mathrm{RBC}$ folate $360 \mathrm{nmol} / \mathrm{L}$ are considered to be satisfactory; those between $7-14 \mathrm{nmol} / \mathrm{L}$ serum folate and 320-360 nmol/L RBC folate are considered to be low and suggestive of risk. Values lower than these indicate clear deficiency of folate. Normal body stores are estimated at $5-10 \mathrm{mg}$, half of which is in the liver. The turnover rate is estimated to be less than $1 \%$ per day. The measurement of plasma concentrations of homocysteine is shown to be a good indicator of folate and vitamin $\mathrm{B}_{12}$ status. A striking negative correlation between serum folate and protein bound homocysteine is reported (Kang et al. 1987).

\section{Folate nutrition in Indians}

There are no detailed studies on folate nutritional status in the Indian population. However, there are some studies which have been conducted in pregnant women (Raman et al. 1989; Neela \& Raman, 1997) indicating that folate status may be poor in these vulnerable segments of the population (Table 1). The folate nutriture in pregnant women of low-income group who had not received any antenatal care was reported by Raman et al. (1989). Based on RBC folate levels, the folate deficiency during different gestational periods ranged between $40.5 \%$ and $53.3 \%$. Considering the lower cut off used for defining per cent deficient folic acid, these figures could be an underestimate of the actual prevalence existing in poor communities.

Poor folate content of human fetal liver was reported by Iyengar \& Apte (1972). The mean total liver folate value increased from $95 \mu \mathrm{g}$ to $262 \mu \mathrm{g}$ depending on the age of the fetus ( $<28$ to $37-40 w k)$. A study was carried out in pregnant women belonging to the poor sections of the population attending a local government hospital receiving $60 \mathrm{mg}$ iron with or without folic acid and followed up from 20 to 24 weeks of pregnancy to term and 6 weeks postpartum. The red cell folate levels decreased from $329 \pm 129 \mathrm{nmol} / \mathrm{L}$ at term to $256 \pm 118 \mathrm{nmol} / \mathrm{L}$ postpartum in women who did not receive folic acid supplement. The levels of red cell folate were not different from the initial value in the group which received $100 \mu \mathrm{g}$ folic acid $(n=21)$. Significantly higher levels were observed only with $200 \mu \mathrm{g}(n=25)$ and $300 \mu \mathrm{g}(n=23)$ of folic acid supplementation; the increments were $91 \mathrm{nmol} / \mathrm{L}$ and $195 \mathrm{nmol} / \mathrm{L}$ respectively (Iyengar, 1971). A subsequent study with $500 \mu \mathrm{g}$ folic acid given with $60 \mathrm{mg}$ iron showed a reduction in the per cent of small for date births $(<2.5 \mathrm{~kg})$ from $30 \%$ to $16 \%$ (Iyengar \& Rajalakshmi, 1975). The red cell folate levels in infants born to mothers who received $300 \mu \mathrm{g}$ of folic acid were higher than those born to the control group. The birth weights of infants born to mothers who had received either 200 or $500 \mu \mathrm{g}$ folic acid daily were higher than those born to mothers who had not received any supplements (Iyengar \& Rajalakshmi, 1975). The above studies clearly indicate folate deficiency in the population.

\section{Etiology of folate deficiency}

Folic acid deficiency can arise in a variety of settings such as low dietary intake, increased demands during growth periods (infancy and puberty), lactation and pregnancy, malabsorption, conditions of hemolysis such as hemolytic anemias and malignancy such as leukemias. Drug induced folate deficiency is encountered in epileptics, ulcerative colitis, etc. Chronic alcoholism is associated with folate deficiency. Advanced folate deficiency, characteristically produces macrocytic or megaloblastic anemia with hematological features similar to vitamin $\mathrm{B}_{12}$ deficiency. However, mucous membrane lesions and other clinical manifestations such as neural tube defects (Lemire, 1988) or more recently, hyper homocysteinemia with characteristic vascular damage are well-recognized (Graham et al. 1997). Additional nutritional stress in pregnancy and during infancy appears to be an important clinical problem that is of public health significance. Folic acid may also be associated with a variety of pregnancy complications such as spontaneous abortions, bleeding, abruptio placenta and pre-eclampsia.

The two important diseases in relation to folate status are neural tube defects (NTD) and homocysteinemia. In recent years, interest in plasma homocysteine has been growing rapidly. Epidemiological data linking moderate elevations in plasma homocysteine to higher prevalence of occlusive 
vascular diseases such as coronary artery disease (CAD) and stroke are now emerging.

\section{Consequences of homocysteinemia}

Folic acid is essential for the methylation of homocysteine (Hcy) to form methionine and the biosynthesis of deoxynucleotides needed for DNA replication. Increased Hcy has been associated with premature vascular disease (Boushey et al. 1995; Graham et al. 1997) and decreased lymphocyte DNA methylation in postmenopausal women (Jacob et al. 1998). Homocysteine has been implicated in mental retardation in children, developmental defects, occlusive disorders, osteoporosis and dislocated lenses with lack of cystathionine betasynthase in the homozygous state.

There is evidence that hyperhomocysteinemia is an independent risk factor for ischemic heart disease (Wald et al. 1998). The relative increase in risk of coronary heart diseases for men and women respectively was 1.6 and 1.5 for each increment of $5 \mu \mathrm{mol} / \mathrm{L}$ in total plasma Hcy (National Academy of Sciences, 1998; Boushey et al. 1995). These findings are in agreement with the Norwegian Study relating prospective cardiovascular mortality risk to elevated Hcy levels (Nygard, 1997).

The recent study on lowering blood Hcy with $400 \mu \mathrm{g}$ folic acid based supplements indicated that a daily intake of $400 \mu \mathrm{g}$ of folate and $3 \mathrm{mg}$ vitamin $\mathrm{B}_{6}$ may potentially help reduce cardiovascular mortality (Rimm et al. 1998).

\section{What is the current scenario in India?}

There are no systematic studies on plasma Hcy levels. The two preliminary studies on subjects with CAD show that Hcy is not a strong risk factor (Chacko, 1998; Gheye et al. 1999). In both the studies the subjects belonged to the middle socio-economic class. Serum Hcy levels were similar in CAD patients and controls. The Hcy levels varied from 2.98 to $63.36 \mu \mathrm{mol} / \mathrm{L}(10.98 \pm 9.04)$ in fiftysix CAD patients and 3.74 to $19.62 \mu \mathrm{mol} / \mathrm{L}(9.41 \pm 3.60)$ in fifty-three control subjects (Chacko, 1998). Though the mean (SE) total Hcy levels of $21.5 \pm 2.33(n=58)$ and $19.7 \pm 1.87 \mu \mathrm{mol} / \mathrm{L}$ respectively in $\mathrm{CAD}$ patients and in age and socio economic status matched controls was comparable (Gheye et al. 1999), they were higher than the upper cut off of the normal value of 7-17 $\mu \mathrm{mol} / \mathrm{L}$ reported for the Western population (Jacobsen, 1996). There is evidence of greater vulnerability of South Asian migrants in US to CAD and diabetes as compared to the native populations. This increased susceptibility is reflected by the prevalence of syndrome ' $\mathrm{X}$ ' characterized by abdominal obesity, hyperinsulinemia, hypertriglyceridemia, low concentration of HDL and hypertension. The high risk of CAD in this population group is probably due to ' $\mathrm{X}$ ' syndrome, a consequence of fetal malnutrition (Gopalan, 1994). The role of hyperhomocysteinemia as a risk factor in India needs to be investigated.

\section{Etiology of homocysteinemia}

Homocysteine levels in plasma are determined by nutritional, physiological, genetic and pathological factors (Welch \& Loscalzo, 1998).

\section{Nutritional factors}

Three vitamins of the B-complex group — folate, vitamin $\mathrm{B}_{12}$ and riboflavin are involved in the different reactions of Hcy metabolism. It is therefore, conceivable that the deficiencies of these vitamins may influence the levels of plasma Hcy. Well-documented evidence exists only for folate. Studies in both animals and humans have shown that folate deficiency is associated with marked elevation in plasma Hcy levels (normal range $7-17 \mu \mathrm{mol} / \mathrm{L}$ ) without evidence of megaloblastosis and hypersegmentation of neutrophil (Jacob et al. 1994). A strong negative correlation between folate status and Hcy levels in plasma has been observed. Subjects with even marginal deficiency of folate ( $<7 \mathrm{nmol} / \mathrm{L}$ serum folate) have been found to have elevated levels of Hcy suggesting that folate requirements to correct this abnormality may be higher (Jacob et al. 1998). Elevated levels of plasma Hcy were also reported in those over 80 years of age than in younger subjects (Selhub et al. 1993; Tucker et al. 1996). Several recent studies show reduction in Hcy levels on folate supplementation, both in homocysteinemic subjects as well as normals (Homocysteine Lowering Trialists' Collaboration, 1998; Dierkes et al. 1998; Malinow et al. 1998). These results suggest that folic acid fortified cereals and supplements can certainly decrease the plasma Hcy levels.

\section{Physiological factors}

Sex difference exists in plasma Hcy levels. Young women (premenopausal) tend to have $25 \%$ lower levels than men. This difference decreases after menopause, perhaps suggesting beneficial effects of female sex hormones. A strong correlation between plasma estrodiol levels and Hcy in post-menopausal women has been reported (Wouters et al. 1995). There is a progressive decrease in plasma Hcy levels during pregnancy but the exact mechanism for this reduction is not known. This has been attributed to lower plasma albumin that binds Hcy and/or increased cortisol level during pregnancy. Male sex and older age are thus associated with hyperhomocysteinemia.

\section{Genetic factors}

Methylenetetrahydrofolate reductase (MTHFR) catalyses the irreversible conversion of 5-10 methylene tetrahydrofolate to 5-methyl tetrahydrofolate. Homozygous deficiency of MTHFR due to a new type of point mutation of the thermolabile MTHFR has been reported (Kang et al. 1988; Ma et al. 1997; Choi et al. 1999). A common polymorphism of this gene, a specific C-T substitution at nucleotide position 677 of the MTHFR gene (C677T) causes the thermolability and reduced activity of this enzyme. About $10 \%$ of the urban Canadian population has this defect suggesting a high frequency mutation (Frosst 
et al. 1995). These subjects have a $50 \%$ reduction in the activity of this enzyme and a tendency for higher levels of plasma Hcy, particularly in individuals with low folate nutritional status.

\section{Life-style factors}

A life-style profile characterized by low folate intakes, smoking and high coffee consumption were the strongest determinants of plasma Hcy concentrations. The folate deficient tissues are thought to be more susceptible to neoplastic transformation by carcinogens in the smoke (Heinburger et al. 1988).

\section{Drugs}

Methotrexate is an antifolate drug that is widely used in the treatment of acute leukemia and some solid tumors. Low doses of this drug are also used in the management of psoriasis and rheumatoid arthritis. Methotrexate is metabolized intracellularly to polyglutamates and both the parent drug and its metabolites inhibit dihydrofolate reductase, the enzyme responsible for the conversion of dihydrofolate to tetrahydrofolate. This results in the lower folate level and impairment of folate functions at cellular levels. Similar observation was made in children with acute leukemia. Initially plasma Hcy levels were high and chemotherapy with methotrexate as well as other cytotoxic agents reduced Hcy level parallel to reduction in leukemic cell count (Ueland \& Refsum, 1989).

Anticonvulsant drugs like pheynytoin, phenobarbital, premedian, carbamazepine cause folate deficiency (Elsborg, 1974; Collins et al. 1988; Young \& Ghadirian, 1989). The proposed mechanisms include reduced folate absorption, increased metabolism of folate in the liver and altered activities of some of the enzymes involved in one carbon transfer.

\section{Folic acid and cancer}

Folic acid has been used as an antagonist for cancer therapy for the last 40 years. An issue of interest is whether folic acid deficiency is etiologically related to cancer specific sites such as colorectal cancer (Giovannucci et al. 1993; Choi \& Mason, 2000). Folate deficiency is highly prevalent in many developing countries where the incidence of colorectal cancer is low, implying that other environmental factors are probably responsible to enhance cancer risk. There are studies to indicate that low red cell folate is associated with increased risk of cervical dysplasia especially carcinoma in situ (Butterworth et al. 1982). High dietary intakes of folate along with vitamin $\mathrm{C}$ and carotene have been observed to decrease the risk of carcinoma in situ.

\section{Neural tube defects (NTD)}

Spina bifida and anencephaly are birth defects of multifactorial etiology related to neural tube closure. Anencephaly is characterized by the absence of forebrain and spina bifida is characterized by incomplete fusion of the vertebral arches with protruding sac with meninges, spinal cord and nerve roots. The role of folic acid in reducing the rate of NTD has been well-established (National Academy of Sciences, 1998). Pre-conceptional administration of folic acid can reduce women's risk of having a fetus or infant with a NTD. Several observational studies and randomized trials suggest that peri-conceptional folic acid supplementation lowers the risk of neutral tube defects and currently, the consensus is that all women of child bearing age must consume $400 \mu \mathrm{g}$ of folic acid per day to reduce their risk of having a child with NTD (Berry et al. 1999; Cuskelly et al. 1996; de Bree et al. 1997; Scott et al. 1994).

\section{Prevalence}

There is significant geo-ethnic variation in the prevalence of NTDs worldwide (Table 2). In United States a decrease in the prevalence of NTDs at birth has been reported. The current rates vary from 0.72 to 1.03 per 1000 births in different states (National Academy of Sciences, 1998). It has been pointed out that anencephaly is relatively uncommon in people with African origin while it is very common in Northern Ireland and Wales (6.38 to $10 \cdot 9 / 1000$ births) (Lemire, 1988). The other population with high rates of NTDs includes the Northern Chinese population (Berry et al. 1999). The difference in the NTD in northern and southern regions of China suggests that factors other than ethnic background may have a role.

In India, large-scale epidemiological studies have been conducted to determine prevalence of NTD (Table 2). In general, the prevalence of NTDs is considerably high and varies in different parts of the country (Sharma \& Gulati, 1992; Agarwal, 1998). Southern India and the Western parts of the country apparently have lower rates except Davangere in Karnataka where the prevalence is quite high at 11.4/1000 births (Kulkarni et al. 1989). Data from a teaching hospital in Lucknow indicates a prevalence of $4.7 /$ 1000 births (Agarwal et al. 1991).

Table 2. Frequency of neural tube defects in India, USA, Canada, UK and China

\begin{tabular}{|c|c|c|c|}
\hline India† & $\begin{array}{l}\text { NTD } 1000 \\
\text { births }\end{array}$ & $\begin{array}{l}\text { USA and } \\
\text { Canadał }\end{array}$ & $\begin{array}{l}\text { NTD } 1000 \\
\text { births }\end{array}$ \\
\hline Amritsar & 8.0 & Arkansas & 1.03 \\
\hline Jaipur & 5.6 & Atlanta & 0.99 \\
\hline Udaipur & 7.8 & California & 0.94 \\
\hline Chandigarh & 12.0 & lowa & 0.90 \\
\hline Delhi & 4.1 & Hawaii & 0.92 \\
\hline Lucknow & 4.7 & Quebec & 1.41 \\
\hline Rajasthan & 18.0 & & \\
\hline Ajmer & 6.6 & & \\
\hline Calcutta & 1.1 & UK§ & \\
\hline Patna & 5.3 & Northern Ireland & 6.38 \\
\hline Mumbai & 2.2 & Wales & 10.9 \\
\hline Chennai & 2.3 & Chinaף & \\
\hline Mysore & 1.5 & Northern region & 6.5 \\
\hline Davangere & 11.4 & Southern region & 0.8 \\
\hline Wardha & 3.9 & & \\
\hline
\end{tabular}

† Sharma \& Gulati, 1992; Kulkarni \& Jose, 1997; Kulkarni et al. 1989. ¥ National Academy of Sciences (1998). §Lemire 1988. ๆBerry et al. 1999. 


\section{Etiology}

Etio-pathogenetically, NTD is a heterogenous entity and is multifactorial in origin (Dolk et al. 1991) with a strong genetic component (Emery, 1986). It is believed to be polygenic, probably involving multiple genes. The high prevalence of NTDs in certain parts of India has been attributed to high rates of consanguinity (Kulkarni et al. 1989). The dengue viral infection has also been suggested as a possible factor by Sharma \& Gulati (1992) based on the cluster of NTDs that appeared in the Rohtak district of Haryana, India. Several other factors such as previous fetal loss, maternal epilepsy, teenage pregnancy, rubella, diabetes and poor socio-economic status have been reported to increase the risk of NTD. The incidence of NTD is high in the Sikh community (Stevenson et al. 1966; Chambers et al. 1994).

Among the environmental factors, nutrition has been identified as an important contributor to this disease. The lower the plasma folate, the higher is the number of NTDs, the picture with respect to erythrocyte folate is similar. The reduction in risk of neural tube defects by folic acid supplementation has been conclusively shown in controlled intervention trials (Scott et al. 1995; Locksmith \& Duff, 1998). The mechanism by which adequate folate intake reduces the risk during the crucial developmental phase of the embryonic neural tube is unknown. Increasing folate intake, which increases the concentrations of folate coenzymes in tissues, may overcome an unidentified metabolic defect at the time of neural tube development and closure (National Academy of Sciences, 1998).

\section{Control of neural tube defects}

Results of several double blind randomized trials support the beneficial effect of folic acid supplementation in reducing the incidence of NTD (Laurence et al. 1981; National Academy of Sciences, 1998). The Medical Research Council of Great Britain conducted an intervention study in women with previous history of NTD and showed a $72 \%$ reduction in the risk of having an affected fetus or infant in women who took $400 \mu \mathrm{g}$ folic acid (MRC Vitamin Study Research Group, 1991). A 30-40\% reduction in NTD-affected pregnancies among women whose average dietary intake of methionine was above the lowest quartile of intake $(>1.34 \mathrm{~g} / \mathrm{d})$ was reported by Shaw et al. (1997). A recent study from China (Berry et al. 1999) suggests that the daily ingestion of $400 \mu \mathrm{g}$ of folic acid alone during the periconceptional period may help reduce the rate of the first occurrence of NTDs in many parts of the world. The risk can be considerably decreased by increasing the folate intake to $400-500 \mu \mathrm{g}$ while planning pregnancy and continuing upto the twelfth week of pregnancy. Periconceptional folate supplementation has been encouraged in the UK since the early 1990s, but no concurrent decline in NTD pregnancies has been observed by regional congenital anomaly registers (Abramsky et al. 1999).

Currently, food fortification is implemented for prevention of NTD (Bailey, 1998). Considering the strong association of folic acid and NTDs and low intake of food folate of $110-140 \mu \mathrm{g} / \mathrm{d}$ as against an RDA of $200 \mu \mathrm{g} /$ $\mathrm{d}$ by the women of child bearing age in the United States, fortification of cereal-grain products with folic acid is mandated by the FDA. It has been estimated that the level of folic acid fortification of $140 \mu \mathrm{g} / 100 \mathrm{~g}$ cereal-grain product recommended by the FDA would increase folic acid intake by $80-100 \mu \mathrm{g} / \mathrm{day}$ in this group of women. Consequently, as of 1 January 1998 cereal-grain products in the US food supply are being fortified with folic acid to prevent NTDs (Malinow et al. 1998).

In India there are no such studies demonstrating the beneficial effects of folic acid supplementation on prevention of NTDs. The limited Indian experience also shows that folic acid can prevent NTD (Kulkarni \& Jose, 1997). It is, however, pertinent to mention that a National Nutritional Anemia Control Programme for pregnant women has been in operation since 1970 which envisages a supply of 60 or $100 \mathrm{mg}$ of iron with $500 \mu \mathrm{g}$ folic acid per day for 100 days (Ministry of Health and Family Welfare, 1970; Indian Council of Medical Research, 1989; Indian Council of Medical Research, 1992). An evaluation in eleven States during 1985-86 indicated very poor coverage and performance of the programme. The folic acid content in these tablets was $35 \%$ or less than the expected level (Vijararaghavan et al. 1990). To what extent the above programme contributes to folate nutriture under the programmatic conditions is not known. Thus, there is a need to have countrywide data on folate status, food folate levels, and bioavailability to facilitate intervention measures.

\section{Recommended dietary intake of folate}

Folate requirements have been defined as the quantity of intake necessary to prevent severe deficiency with clinical symptoms (National Academy of Sciences, 1989). Currently, the focus has shifted to identifying intakes associated with maintenance of normal biochemical function such as one-carbon transfer reactions. Abnormalities identified in the metabolic pathways such as hyperhomocysteinemia, hypomethylation of DNA and uracil misincorporation are assigned as functional indicators of folate status (Selhub et al. 1993; Green \& Jacobsen, 1995; Blount et al. 1997; Jacob et al. 1998). Risk reduction for chronic diseases and developmental defects (NTD) have also been used for deriving optimum folate intakes (Boushey et al. 1995; Daly et al. 1997). Stable isotopically labeled folate is also used in defining the folate requirement more accurately (Gregory et al. 1998).

Based on recent studies, the National Academy of Sciences (1998) have reported new dietary reference intakes (DRI) for folate. The DRI for folate includes folate requirement estimation for population groups referred to as the estimated average requirement (EAR). EAR is defined as the amount of folate that is needed to meet the requirement of $50 \%$ of the population. The recommended dietary allowances (RDA) were derived from the EAR by correcting for population variance which is defined as the average level of daily dietary intake to meet the requirement of $98 \%$ of the population. The basis for deriving EAR and RDA for folate was mainly based on the study of 
Table 3. Recommended dietary intake (RDI) $(\mu \mathrm{g} / \mathrm{d}) \dagger$ for folate for the adult population

\begin{tabular}{|c|c|c|c|c|c|}
\hline \multirow[b]{2}{*}{ Country } & \multirow[b]{2}{*}{ Minimum requirements } & \multirow[b]{2}{*}{ Individual variation } & \multirow[b]{2}{*}{ Bioavailability } & \multicolumn{2}{|c|}{ Recommended } \\
\hline & & & & Male & Female \\
\hline FAO/WHO & 60 & $+15 \%$ & $+70 \%$ & 200 & 170 \\
\hline USA & & $+20 \%$ & $+50 \%$ & $320 \ddagger$ & $320 \ddagger$ \\
\hline UK & 100 & $+?$ & $+50 \%$ & 200 & 200 \\
\hline The Netherlands & 50 & $+200-300 \%$ & $+50 \%$ & $200-300$ & $200-300$ \\
\hline France & 50 & $?$ & $?$ & 300 & 300 \\
\hline Germany & 150 & ? & $+50 \%$ & 300 & 300 \\
\hline India & 75 & ? & $+50 \%$ & 100 & 100 \\
\hline
\end{tabular}

† de Bree et al. 1997; National Academy of Sciences (1998); Indian Council of Medical Research, 1989. $\ddagger$ Dietary folate equivalents (DFE).

O'Keefe et al. (1995). The DRIs for folate are expressed as Dietary Folate Equivalents (DFE), a term used to adjust for the generally higher bioavailability of synthetic folic acid relative to most forms of naturally occurring folate in foods (National Academy of Sciences, 1998; Bailey, 1998). It is estimated that $85 \%$ of synthetic folic acid is bioavailable when consumed with food, while the bioavailability of food folate as such is only $50 \%$ that of synthetic folic acid.

For male and female adults over 19 years of age, the folate EAR and RDA are 320 and $400 \mu \mathrm{g}$ DFE/d respectively (Table 3 ). For pregnant women, the corresponding figures are 520 and $600 \mu \mathrm{g}$ DFE/d. Subsequent studies with folate intake of $600 \mu \mathrm{g}$ DFE/d were shown to be adequate to maintain normal folate status in pregnant women (Bonnette et al. 1998; Caudill et al. 1997; Caudill et al. 1998).

The current RDA for folate in Indians is based on the following literature evidences. The free and total folate levels in Indian foods have been determined microbiologically using $L$. casei as the organism (Gopalan et al. 1989). Studies on the actual availability of food folate are few. Dietary surveys in Indian subjects show that predominantly cereal based diets provide about $70 \mu \mathrm{g}$ folic acid a day (NNMB, 1999). The bioavailability of folate from a typical Indian diet varied from 60 to $70 \%$ in pulses and green leafy vegetables and about $50 \%$ in vegetables (Babu \& Srikantia, 1976). In a repletiondepletion study in Indian human volunteers, $75 \mu \mathrm{g}$ of folate was found to be adequate to maintain optimal concentrations of folate both in serum and red blood cells (Babu, 1976b). Based on this, the safe level of folate intake was fixed at $100 \mu \mathrm{g} / \mathrm{day}$. Due to lack of precise information on bioavailability of food folates, the ICMR Committee had recommended a RDA of $100 \mu \mathrm{g}$ of free folate for adults (Table 4). The results of the study of Iyengar (1971) in Indian women have suggested that between 200 and $300 \mu \mathrm{g}$ of folates are needed to maintain plasma and red cell folate in the normal range during pregnancy. Based on this, an amount of $400 \mu \mathrm{g} /$ day of additional folic acid is suggested for pregnant women. The estimated folate content of breast milk secreted by Indian women is $16 \mu \mathrm{g} / \mathrm{L}$ (Ramasastry, 1965) which is twice as low as that reported from the west. Therefore, an additional allowance of $50 \mu \mathrm{g}$ of folate is recommended $(150 \mu \mathrm{g} / \mathrm{d})$ for lactating women (Indian Council of Medical Research, 1989).

The dietary intake of folate in different countries varies considerably from 100 to $300 \mu \mathrm{g} / \mathrm{d}$. The most recent Indian data from the NNMB (1999) indicate that the mean folate intake is around $150 \mu \mathrm{g}$ (Fig. 1, Table 4) and appears to meet the RDA. However, the intake of folic acid was less than the RDI of $200 \mu \mathrm{gm} / \mathrm{d}$ in all states, except Gujarat. The intakes are also much higher in other countries compared to India (Table 3).

Even though the minimum requirements are around 50 to $150 \mu \mathrm{g}$ considering the factors such as individual variations and bioavailability, the recommendations are in the range of 170-320 $\mu \mathrm{g}$ of food folate (Table 3 ). However, as stated earlier, the desired folate intake would have to be much higher than these levels to reduce the prevalence of some of the more recent clinical situations (Table 5). As it is difficult to obtain the adequate level of folate from food, the entire western world has initiated implementation of food fortification, this being the most cost-effective way of reducing the adverse health effects of folic acid (Malinow et al. 1998; National Academy of Sciences, 1998).

The recommended folate intake needs revision in the Indian context. Though promoting voluntary use of folate supplementation is a potential short-term strategy, it is difficult to implement in the Indian situation. In addition to pharmacological approaches, we therefore also need to think in terms of food fortification. These potential

Table 4. Recommended dietary allowances of folic acid in Indians and current intake of folate

\begin{tabular}{lcc}
\hline & $\begin{array}{c}\text { RDA } \mu \text { of free } \\
\text { folate/day† }\end{array}$ & $\begin{array}{c}\text { Current RDI } \\
\mu \mathrm{g} / \text { day }\end{array}$ \\
\hline Men & 100 & $182 \cdot 0$ \\
Women & 100 & $154 \cdot 9$ \\
Pregnant women & 400 & $145 \cdot 7$ \\
Lactating women & 150 & $165 \cdot 5$ \\
Infants & 25 & - \\
0-12 months & & \\
Children & 30 & $57 \cdot 5$ \\
$1-3$ y & 40 & $93 \cdot 5$ \\
$4-6$ y & 60 & $115 \cdot 4$ \\
$7-9$ y & & $133 \cdot 2$ \\
Boys, Girls & 70 & $126 \cdot 1$ \\
$10-12$ y & & $148 \cdot 2$ \\
$13-15$ & 100 & $142 \cdot 4$ \\
$16-18$ & 100 & $178 \cdot 2$ \\
& & $144 \cdot 0$ \\
\hline
\end{tabular}

$†$ Indian Council of Medical Research, 1990. ¥NNMB National Nutrition Monitoring Bureau, 1999. 
Table 5. Recommended folate intake for prevention of homocysteinemia and NTDs

\begin{tabular}{lll}
\hline $\begin{array}{l}\text { Recommended intakes } \\
\text { of folic acid }(\mu \mathrm{g} / \mathrm{d})\end{array}$ & \multicolumn{1}{c}{ Population } & \multicolumn{1}{c}{ Category } \\
\hline 300 & Non-pregnant women & $\begin{array}{l}\text { Allowance for storage } \\
\text { To prevent homocysteinemia }\end{array}$ \\
350 & Adults & Established homocysteinemia \\
650 & Individuals & Prevent NTD \\
400 & Pregnancy & With previous history of NTD \\
4000 & Pregnancy &
\end{tabular}

Sources: de Bree et al. 1997; Sauberlich et al. 1987.

interventions need careful consideration for feasibility, sustainability and effectiveness under programmatic conditions.

\section{Conclusions}

Currently from the dietary intake studies and folate status in pregnant women and children, it has been observed that the incidence of sub-clinical forms of folic acid deficiency is high. Therefore, there is a need for a concerted effort to adopt strategies for preventing NTDs and possibly cardiovascular complications in the adult population. Clinical issues that need consideration relate to an appropriate analogue of folic acid, the stability and cost, its trade and regulatory issues, mechanisms to reach those at high risk, the vehicles which need to be fortified, its procurement, processing and distribution of the same coupled with its quality assurance and control. It must be borne in mind that in addition to the deficiency of iron and other major micronutrients, folic acid has to be given due importance and appropriate steps must be initiated for prevention and control of its deficiency.

\section{References}

Abramsky L, Blotting B, Chapple J \& Stone D (1999) Has advice on periconceptional folate supplementation reduced neural tube defects? Lancet 354, 998-999.

Agarwal SS, Singh U, Singh PS, Singh SS, Das V, Sharma A, Mehra P, Chandravathi, Malik GK \& Misra PK (1991) Prevalence and spectrum of congenital malformations in a prospective study at teaching hospital. Indian Journal of Medical Research 94, 413-419.

Agarwal SS (1998) Folic acid for prevention of neural tube defects. Bulletin of the Nutrition Foundation of India 19, 5-8.

Ahmed F, Bamji MS \& Iyengar L (1975) Effect of oral contraceptive agents on vitamin nutrition status. American Journal of Clinical Nutrition 28, 606-615.

Babu S \& Srikantia SG (1976) Availability of folates from some foods. American Journal of Clinical Nutrition 29, 376-379.

Babu S (1976a) Effect of germination on folic acid content of Bengal gram and ragi. Indian Journal of Nutrition and Dietetics 13, 139-141.

Babu S (1976b) Studies on folic acid. PhD Thesis, Osmania University, Hyderabad, India.

Bailey LB (1998) Dietary reference intakes for folate: the debut of dietary folate equivalents. Nutrition Reviews 56, 294-299.

Berry RJ, Li MPHTMZ, Erickson DJ, Li S, Moare CA, Wang H, Mulinare J, Zhao P, Wong LYC, Gindler J, Hong SX \& Correa A (1999) Prevention of neural tube defects with folic acid in China. New England Journal of Medicine 341, 14851490.

Blount BC, Mack MM, Wehr CM, MacGregor JT, Hiatt RA, Wang G, Wickramasinghe SN, Everson RB \& Ames BN (1997) Folate deficiency causes uracil misincorporation into human DNA and chromosome breaking: Implications for cancer and neuronal damage. Proceedings of the National Academy of Sciences, USA 94, 3290-3295.

Bonnette RE, Caudill MA \& Bailey LB (1998) Plasma homocysteine response to controlled folate intake in pregnant woman. Obstetrics and Gynecology 92, 167-170.

Boushey CJ, Beresford SAA, Omenn GS \& Motulsky AG (1995) A quantitative assessment of plasma homocysteine as a risk factor for vascular disease. Journal of the American Medical Association 274, 1049-1057.

Butterworth CE, Baugh CM \& Krumdieck CL (1969) A study of folate absorption in non-utilizing carbon-14-labeled polyglutamate synthesized by the solid phase method. Journal of Clinical Investigation 48, 1131-1142.

Butterworth CE, Hateh KD, Gore H, Muller H \& Krumdieck CL (1982) Improvement in cervical dysplasia associated with folic acid therapy in users of oral contraceptives. American Journal of Clinical Nutrition 35, 73-82.

Caudill MA, Cruz AC, Gregory JF III, Hutson AD \& Bailey LB (1997) Folate status response to controlled folate intake in pregnant women. Journal of Nutrition 127, 2362-2370.

Caudill MA, Gregory JF III, Hutson AD \& Bailey LB (1998) Folate catabolism in pregnant and non-pregnant women with controlled folate intakes. Journal of Nutrition 128, 204-208.

Chacko KA (1998) Plasma homocysteine levels in-patients with coronary heart disease. Indian Heart Journal 50, 295-299.

Chambers K, Popkin J, Arnold W, Irwin B \& Hall JG (1994) Neural tube defects in British Columbia. Lancet 343, 489-490.

Chandler CJ, Wang TT \& Halsted CH (1986) Pteroylpolyglutamate hydrolase from human jejunal brush borders: Purification and characterization. Journal of Biological Chemistry 261, 928-933.

Choi SW, Lathrop Stem L, Dzia lo HM, Dolnikowski GG, Selhub J \& Mason JB (1999) A common polymorphism in the methylenetetrahydrofolate reductase (MTHFR) gene decreases genomic, DNA methylation, but does not reduce DNA strand breaks, p53 methylation or uracil misincorporation: implication for colorectal carcinogenesis. Gastroenterology 116, 303.

Choi SW \& Mason JB (2000) Folate and carcinogenesis: an integrated scheme. Journal of Nutrition 130, 129-132.

Collins CS, Bailey LB, Hillier S, Cerda JJ \& Wilder BJ (1988) Red blood cell uptake of supplemental folate in patients on anticonvulsant drug therapy. American Journal of Clinical Nutrition 48, 1445-1450.

Cossins EA (1984) Folates in biological materials. In Folates and Pterins, Vol. 1, pp. 1-60 [RL Blakley and SJ Benkovic, editors]. New York: John Wiley and Sons Inc.

Cuskelly GJ, McNulty H \& Scott JM (1996) Effect of increasing 
dietary folate on red cell folate: implications for prevention of neural tube defects. Lancet 347, 657-659.

Daly S, Mills JL, Molloy AM, Conley M, Lee YJ, Kirke PN, Weir DG \& Scott JM (1997) Minimum effective dose of folic acid for food fortification to prevent neural tube defect. Lancet 350, 1666-1669.

Dawson DN \& Waters HM (1994) Malnutrition: folate and cobalamine deficiency. British Journal of Biomedical Science 51, 221-227.

de Bree A, Dusseldorp MV, Brouwer IA, Hof van het KH \& Theunissen RPM (1997) Folate intake in Europe: recommended, actual and desired intake. European Journal of Clinical Nutrition 51, 643-660.

Dierkes J, Kroesen M \& Pietrzik K (1998) Folic acid and vitamin B6 supplementation and plasma homocysteine concentrations in healthy young women. International Journal of Vitamin Nutrition Research 68, 98-103.

Dolk H, BeWals P, Gillerot Y, Lechat MF, Ayme S, Cornel M, Cuschieri A, Garne E, Goujard J \& Laurence KM (1991) Heterogeniety of neural tube defects in Europe: The significance of site of defect and presence of other major anomalies in relation to geographic differences in prevalence. Teratology 44 , 547-559.

Elsborg L (1974) Inhibition of intestinal absorption of folate by phenytoin. Acta Haematologica 52, 24-28.

Emery AE (1986) Methods in Medical Genetics, An introduction to statistical methods. 2nd edition. Edinburgh: Churchill/ Livingstone.

Frosst P, Blom HJ, Milos R, Goyette P, Sheppard CA, Mathews RG, Boers GJ, denHeijer M, Kluijtmans LA, Vanden Heuvel LP \& Rozen R (1995) A candidate genetic risk factor for vascular disease; a common mutation in methylene tetrahydrofolate reductase. Nature Genetics 10, 111-113.

Gheye S, Lakshmi AV, Krishna TP \& Krishnaswamy K (1999) Fibrinogen and homocysteine in coronary artery disease. Indian Heart Journal 51, 499-502.

Giovannucci E, Stampfer M, Colditz G, Rimm E, Trichopolous D, Rosner B, Speizer F \& Willett W (1993) Folate, methionine and alcohol intake and risk of colorectal adenoma. Journal of National Cancer Institute 85, 875-884.

Gopalan C, Ramasastry BV, Balasubramanyam SC, Revised and updated by Narasinga Rao BS, Deosthale YG \& Pant KC (1989) Nutritive Value of Indian Foods. Hyderabad: National Institute of Nutrition, ICMR.

Gopalan C (1994) Late effects of foetal undernutrition. The Bulletin of Nutrition Foundation of India 15, 1-4.

Graham IM, Daly LE, Refsum HM, Robinson K, Brattstrom LE, Ueland PM, Palma-Reis RJ, Boers GH, Sheahan RG, Israelsson $\mathrm{B}$, Uiterwaal $\mathrm{CS}$, Meleady $\mathrm{R}$, McMaster $\mathrm{D}$, Verhoef P, Witteman J, Rubba P, Bellet H, Wautrecht JC, de Valk HW, Sales Luis AC, Parrot-Rouland FM, Tan KS, Higgins I, Garcon D \& Andria G (1997) Plasma homocysteine as a risk factor for vascular disease. Journal of the American Medical Association 277, 1775-1781.

Green R \& Jacobsen DW (1995) Clinical implications of hyperhomocysteinemia. In Folate in Health and Disease, pp. 195-235 [LB Baily, editor]. New York: Marcel Dekker.

Gregory JF (1997) Bioavailability of folate. European Journal of Clinical Nutrition 51, S54-S59.

Gregory JF, Williamson J, Liao J-F, Bailey LB \& Toth JP (1998) Kinetic model of folate metabolism in non-pregnant women consuming $\left[{ }^{2} \mathrm{H}_{2}\right]$ folic acid: isotopic labelling of urinary folate and the catabolite PABG indicates slow intake-dependent turnover of folate pools. Journal of Nutrition 128, 1896-1906.

Heinburger DC, Alexander CB, Birch R, Batterworth CE, Bailey WC \& Bumdieck K (1988) Improvement of bronchial metaplasia in smokers treated with folate and vitamin $B_{12}$ (report of a preliminary randomized, double-blind intervention trial). Journal of the American Medical Association 259, 15251530 .

Homocysteine Lowering Trialists' Collaboration (1998) Lowering blood homocysteine with folic acid based supplements; metaanalysis of randomized trials. British Medical Journal 316, 894-898.

Indian Council of Medical Research (1989) Evaluation of National Nutritional Anaemia Prophylaxis Programme. New DelhiA report of a Task Force Study, ICMR.

Indian Council of Medical Research (1990) Nutrient Requirements and Dietary Allowances for Indians. Hyderabad, IndiaNational Institute of Nutrition, ICMR.

Indian Council of Medical Research (1992) Field supplementation trial in pregnant women with $60 \mathrm{mg}, 120 \mathrm{mg}$ and $180 \mathrm{mg}$ of iron with $500 \mu \mathrm{g}$ of folic acid. New DelhiA Report of a Task Force Study, ICMR.

Iyengar L (1971) Folic acid requirements in Indian pregnant women. American Journal of Obstetrics and Gynecology 111, $13-16$.

Iyengar L \& Apte SV (1972) Nutrient stores in human foetal liver. British Journal of Nutrition 27, 313-317.

Iyengar L \& Babu S (1975) Folic acid absorption in pregnancy. British Journal of Obstetrics and Gynaecology 82, 20-23.

Iyengar L \& Rajalakshmi K (1975) Effect of folic acid supplement on birth weights of infants. American Journal of Obstetrics and Gynecology 122, 332-336.

Jacob RA, Wu MM, Henning SM \& Swendseid ME (1994) Homocysteine increase as folate decreases in plasma of healthy men during short term dietary folate and methyl group restriction. Journal of Nutrition 124, 1072-1080.

Jacob RA, Gretz DM, Taylor PC, James JS, Pogribny PI, Miller BJ, Henning SM \& Swendseid ME (1998) Moderate folate depletion increases plasma homocysteine and decreases lymphocyte DNA methylation in postmenopausal women. Journal of Nutrition 128, 1204-1212.

Jacobsen DW (1996) Determinants of hyperhomocysteinemia. A matter of nature and nurture. American Journal of Clinical Nutrition 64, 641-642.

Kang SS, Wong PWK \& Norusis M (1987) Homocysteinemia due to folate deficiency. Metabolism 36, 458-462.

Kang SS, Wong PW, Zhou JM, Sora J, Lessick M, Ruggie N \& Grcevich G (1988) Thermolabile methylene tetrahydrofolate reductase in patients with coronary artery disease. Metabolism 37, 611-613.

Kulkarni ML, Mathew MA \& Reddy V (1989) The range of neural tube defects in South India. Archives of Disease in Childhood 64, 201-204.

Kulkarni ML \& Jose S (1997) Folic acid prevents neural tube defects in high prevalence area. Indian Pediatrics 34, 561-562.

Laurence KM, James N, Miller MH, Tennant GB \& Campbell H (1981) Double blind randomised controlled trial of folate treatment before conception to prevent recurrence of neural tube defects. British Medical Journal 282, 1509-1511.

Lemire RJ (1988) Neural tube defects. Journal of the American Medical Association 259, 558-562.

Locksmith GJ \& Duff P (1998) Preventing neural tube defects: the importance of periconceptional folic acid supplements. Obstetrics and Gynaecology (United States) 91, 1027-1034.

Ma J, Stampfer MJ, Giovannucci E, Arigas C, Hunter DJ, Fuchs C, Willett WC, Selhub J, Hennekens CH \& Rozen RC (1997) Methylenetetrahydrofolate reductase polymorphism, dietary interactions and risk of colorectal cancer. Cancer Research 57, 1098-1102.

Malinow MR, Duell PB, Hess DL, Anderson PH, Kruger WD, Phillipson BE, Gluckman RA, Block PC \& Upson BM (1998) Reduction of plasma homocysteine levels by breakfast cereal 
fortified with folic acid in patients with coronary heart disease. New England Journal of Medicine 338, 1009-1015.

Ministry of Health and Family Welfare (1970) Prophylaxis against nutritional anaemia among mothers and children. Technical information MCH No. 1, Government of India, New Delhi

MRC Vitamin Study Group (1991) Prevention of neural tube defects: results of the Medical Research Council vitamin study. Lancet 338, 131-137.

National Academy of Sciences (1989) Recommended Dietary allowances. Food and Nutrition Board, 10th edition. Washington DC: National Academy Press.

National Academy of Sciences (1998) Dietary References Intakes: thiamin, riboflavin, niacin, vitamin B6, folate, vitamin B12, patothenic acid, biotin and choline. A report of the Standing Committee on the Scientific evaluation of dietary reference intakes and its Panel on folate, other B-vitamins and choline and Sub-Committee on upper reference levels in nutrients, pp. 196-305. Food and Nutrition Board, Institute of Medicine. Washington DC: National Academy Press.

NNMB (1999) National Nutrition Monitoring Bureau - Report of second repeat survey - rural (1996-97), National Institute of Nutrition, Indian Council of Medical Research, Hyderabad

Neela J \& Raman L (1997) The relationship between maternal nutritional status and spontaneous abortion. National Medical Journal of India 10, 15-16.

Neuhouser ML, Beresford SA, Hickok DE \& Mosen ER (1998) Absorption of dietary and supplemental folate in women with prior pregnancies with neural tube defects and controls. Journal of American College of Nutrition 17, 625-630.

Nygard O, Nordrehang JE, Refsum HM, Ueland PM, Farstad M \& Vollsett SE (1997) Plasma homocysteine levels and mortality in patients with coronary heart disease. New England Journal of Medicine 337, 230-236.

O'Broin JD, Temperley IJ, Brown JP \& Scott JM (1975) Nutritional stability of various naturally occurring monoglutamate derivatives of folic acid. American Journal of Clinical Nutrition 28, 438-444.

O'Keefe CA, Bailey LB, Thomas EA, Hofler SA, Davis BA, Cerda JJ \& Gregory JF 3rd (1995) Controlled dietary folate affects folate status in non-pregnant women. Journal of Nutrition 125, 2717-2725.

Pfeiffer CM, Rogers LM, Bailey LB \& Gregory JF III (1997) Absorption of folate from fortified cereal-grain products and of supplemental folate consumed with or without food determined by using a dual stable isotope protocol. American Journal of Clinical Nutrition 66, 1388-1397.

Prinz-Langenohl R, Bronstrup A, Thorand B, Hages M \& Pietrzik K (1999) Availability of food folate in humans. Journal of Nutrition 129, 913-916.

Raman L, Subbalaxmi PV, Vasumathi N, Rawal A, Vasanthi G, Parvathi CH, Adinarayana K, Pawashe AB \& Rao KV (1989) Iron and folic acid nutritional status of women in slum. Nutrition Reports International 39, 73-80.

Ramasastry BVC (1965) Folate activity in human milk. British Journal of Nutrition 19, 581-586.

Rimm EB, Willett WC, Hu FB, Sampson L, Colditz GA, Manson JE, Hennekens C \& Stampfer MJ (1998) Folate and vitamin B6 from diet and supplements in relation to risk of coronary heart disease among women. Journal of the American Medical Association 279, 359-364.

Sauberlich HE, Kretsch MJ, Skala JH, Johnson HL \& Taylor PC (1987) Folate requirement and metabolism in non-pregnant women. American Journal of Clinical Nutrition 46, 1016-1028.
Scott JM, Kirke P, Molloy A, Daly L \& Weir D (1994) The role of folate in the prevention of neural tube defects. Proceedings of the Nutrition Society of India 53, 631-638.

Scott JM, Kirke PM \& Wei DG (1995) Folate and neural tube defects. In Folate in Health and Disease, pp. 329-360 [LB Bailey, editor]. New York: Marcel Dekker.

Selhub J, Jacques PF, Wilson PW, Rush D \& Rosenberg IH (1993) Vitamin status and primary determinants of homocysteinaemia in an elderly population. Journal of the American Medical Association 270, 2693-2698.

Seyoum E \& Selhub J (1998) Properties of food folates determined by stability and susceptibility to intestinal pteroylpolyglutamate hydrolase action. Journal of Nutrition 128, 1956-1960.

Sharma JB \& Gulati N (1992) Potential relationship between dengue fever and neural tube defects in a northern district of India. International Journal of Obstetrics and Gynecology 39, 291.

Shaw GN, Velie EM \& Schatter DM (1997) Is dietary intake of methionine associated with a reduction in risk for neural tube defect - affected pregnancies? Teratology 56, 295-299.

Stevenson AC, Johnston HA, Stewart MJP \& Golding DR (1966) Malformation of structure developed from the neural tube. Bulletin of the World Health Organization 34, (Suppl 9), 25-34.

Tamura T \& Stokstad ELR (1973) The availability of food folate in man. British Journal of Haematology 25, 513-532.

Tamura T (1998) Determination of food folate. Journal of Nutrition 9, 285-293.

Tucker KL, Selhub J, Wilson PF \& Rosenberg IH (1996) Dietary intake pattern relates to plasma folate and homocysteine concentrations in the Framingham Heart Study. Journal of Nutrition 126, 3025-3031.

Ueland PM \& Refsum H (1989) Plasma homocysteine, a risk factor for vascular disease; plasma levels in health, disease and drug therapy. Journal of Clinical and Laboratory Medicine 114, 473-501.

vanhet Hof KH, Tijburg LB, Pietrzik K \& Weststrate JA (1999) Influence of feeding different vegetables on plasma levels of carotenoids, folate and vitamin C. Effect of disruption of the vegetable matrix. British Journal of Nutrition 82, 203-212.

Vijayaraghavan K, Brahmam GNV, Nair KM, Akbar D \& Prahlad Rao N (1990) Evaluation of National Nutritional Anaemia Prophylaxis Programme. Indian Journal of Pediatrics 57, 183190.

Wagner C (1996) Symposium on the subcellular compartmentation of folate metabolism. Journal of Nutrition 126, 1228S1234 S.

Wald NJ, Watt HC, Law MR, Weir DG, McPartlin J \& Scott JM (1998) Homocysteine and ischemic heart dsease. Archives of Internal Medicine 158, 862-867.

Wang TTY, Chandler CJ \& Halstead CH (1986) Intracellular pteroylpolyglutamate hydrolase from human jejunal mucosa: isolation and characterization. Journal of Biological Chemistry 261, 13551-13555.

Welch GN \& Loscalzo J (1998) Homocysteine and atherosclerosis. The New England Journal of Medicine 338, 1042-1050.

Wouters MG, Moorrees MT, van der Mooren MJ, Blom HJ, Boers GH, Schellekens LA, Thomas CM \& Eskes TK (1995) Plasma homocysteine and menopausal status. European Journal of Clinical Investigation 25, 801-805.

Young SN \& Ghadirian AM (1989) Folic acid and psychopathology. Progress in Neuropsychopharmacology and Biological Psychiatry 13, 841-863. 